\title{
The Genetics of Disorders of Sex Development in Humans
}

\author{
Thomas Ohnesorg $^{\mathrm{a}}$ Eric Vilain ${ }^{\mathrm{b}}$ Andrew H. Sinclair ${ }^{\mathrm{a}}$ \\ ${ }^{a}$ Murdoch Children's Research Institute and Department of Paediatrics, The University of Melbourne,

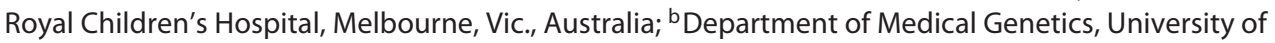 \\ California Los Angeles, Los Angeles, Calif., USA
}

\section{Key Words}

Disorders of sex development - Gonadal development .

Gonadal dysgenesis · Ovary · Sex determination · Sex

reversal. Testis

\begin{abstract}
One of the defining events during human embryonic development with the most far-reaching effects for the individual is whether the embryo develops as male or female. The crucial step in this process is the differentiation of the bipotential embryonic gonads into either testes or ovaries. If the embryo inherits $X$ and $Y$ sex chromosomes, the $Y$-linked SRY (sex determining region in $Y$ ) gene initiates a network of genes that results in a functional testis and ultimately a male phenotype. By contrast, in an embryo with $2 \mathrm{X}$ chromosomes, the undifferentiated gonad develops as an ovary resulting in a female phenotype. Perturbation of any of the genes in either the testicular or ovarian developmental pathway can result in individuals with disorders of sex development. In this review, we provide a summary of known components of testicular or ovarian pathways and their antagonistic actions and give a brief overview of new technologies currently used to identify the missing pieces of the sex development network.

(c) 2014 S. Karger AG, Basel
\end{abstract}

(0) 2014 S. Karger AG, Basel

$1661-5425 / 14 / 0085-0262 \$ 39.50 / 0$
The development of the gonads differs from other organs as they have the potential to differentiate into 2 functionally distinct organs, testes or ovaries. Once functional gonads are formed, hormones released by either testes or ovaries lead to the development of sexual characteristics and eventually to a fertile male or female individual.

In humans and other mammals, sex is determined genetically at fertilization by the sex chromosome constitution. In most mammals (with the exception of monotremes and few species of mole voles and spiny rats), $2 \mathrm{X}$ chromosomes result in ovary (female) development while the inheritance of $\mathrm{X}$ and $\mathrm{Y}$ chromosomes results in testis (male) development. Disorders of sex development (DSD) are defined as congenital conditions in which development of chromosomal, gonadal or anatomical sex is atypical. DSDs range from mild forms of hypospadias to complete sex reversal. Hypospadias occurs with a high frequency of 1 in 250 live births while the incidence of gonadal anomalies is lower and estimated to be 1 in 4,500 live births [Baskin et al., 2001; Hughes et al., 2006].

Patients with DSD have been critical to the discovery of genes responsible for gonadal development. In 1990, the analysis of 46,XX testicular DSD (female-to-male sex reversal) patients with translocation of Y chromosome material to one of the $\mathrm{X}$ chromosomes led to the discovery of the sex determining region $\mathrm{Y}(S R Y)$ gene, which causes

\section{KARGER}

E-Mail karger@karger.com www.karger.com/sxd
Andrew Sinclair

Murdoch Children's Research Institute and Department of Paediatrics The University of Melbourne, Royal Children's Hospital, Flemington Road Melbourne, VIC 3052 (Australia)

E-Mail andrew.sinclair@mcri.edu.au 
the undifferentiated embryonic gonad to develop as a testis [Sinclair et al., 1990]. In the absence of the Y chromosome (and absence of $S R Y$ ), gonads develop as ovaries. Consequently, the crucial event in sex determination is whether or not a testis develops. It is thought that the role of $S R Y$ in this pathway is to initiate a hierarchy of genes eventually leading to testis development.

Since Jost's discovery in the 1940s that the removal of embryonic gonads of rabbits leads to a female phenotype (regardless of the chromosome constitution), the female pathway was long thought to be a passive or 'default' pathway. However, mounting evidence contradicts this hypothesis as it is becoming clearer that components of both male and female differentiation pathways act by suppressing components of the opposing pathway to ensure proper development and maintenance of the gonads (see below).

Since the discovery of $S R Y$ as the master switch in male development, several autosomal genes with important functions in either male or female development have been identified. However, there are still extensive gaps in our understanding of the complex genetic networks leading to either functional testes or ovaries. At present, the majority of DSD cases cannot be explained. This strongly suggests that important components of the sex development pathways are yet to be discovered. Recent technological advances like SNP arrays (to detect copy number variation in the genome) and massively parallel sequencing are likely to lead to new and important findings allowing us to better elucidate the mechanism of human sex determination and differentiation.

Genetic diagnoses for DSDs have become the first step which families can use to build a future and address their many anxieties. The advances in genomic technologies translate to clinical diagnoses and provide a much-needed management guide to patients, families and practitioners. In addition, progress in genomic analyses has allowed better-defined categorizations of patients with DSDs and therefore better, evidence-driven outcome studies. In this review, we will mostly focus on genes involved in the first steps of gonadal sex determination, namely the formation of the undifferentiated gonad and the development of the testis or the ovary.

\section{Formation of the Undifferentiated Gonad}

At early stages of mammalian embryonic development, the embryos are sexually undifferentiated. The undifferentiated gonads derive from the intermediate mesoderm and arise as paired thickenings of the coelomic epi- thelium on the ventromedial surface of the mesonephros [Satoh, 1985]. A distinct feature of the gonads is that, in contrast to other organs, they can develop into 2 functionally different structures, testes and ovaries.

\section{Genes Required for Early Undifferentiated Gonad Formation}

Steroidogenic factor $1(N R 5 A 1 / S F 1)$ is a member of the orphan nuclear receptor family and a key transcription factor involved in the regulation of many steroidogenic enzymes [Val et al., 2003]. In mice, $S f 1$ is expressed from the earliest stages in the urogenital ridge. $S f 1$ is downregulated during ovarian development but shows continued expression throughout testicular development [Luo et al., 1994]. In the testis, $S f 1$ expression is restricted to Sertoli and Leydig cells. However, its expression in all primary steroidogenic tissues, including the developing hypothalamus and pituitary gonadotropes, suggests a role in additional levels of the reproductive axis. Interestingly, $S f 1$ knockout mice lack both adrenal glands and gonads. These mice develop as phenotypic females but die soon after birth due to adrenal failure [Luo et al., 1994]. In humans, mutations of SF1 are known to cause 46,XY DSD gonadal dysgenesis, premature ovarian insufficiency and adrenal failure [Achermann et al., 1999; Lourenço et al., 2009]. Taken together, this data indicates a role for $S F 1$ in the formation of the undifferentiated embryonic gonads as well as in subsequent gonadal sex determination.

The Wilms' tumor 1 (WT1) gene encodes a zinc finger protein. It can act as a transcriptional repressor or activator depending on the cellular or chromosomal context [Hohenstein and Hastie, 2006]. It is also known to be associated with a pediatric kidney cancer. Denys-Drash syndrome, characterized by renal failure and genital abnormalities, including 46,XY gonadal dysgenesis, can be caused by heterozygous mutations in the zinc finger domain of WT1 [Pelletier et al., 1991]. A mutation in a splice donor site in WT1 leads to the loss of a specific isoform of WT1, causing Frasier syndrome and associated 46,XY DSD gonadal dysgenesis [Barbaux et al., 1997]. In the mouse, $W t 1$ is expressed in the undifferentiated gonads at the same time as $S f 1$. Wt1 null mice fail to develop both kidneys and gonads [Kreidberg et al., 1993]. WT1 acts together with SF1 early in urogenital development to ensure proper formation of the undifferentiated gonad [Wilhelm and Englert, 2002]. Mutations in WT1 leading to 46 ,XY DSD gonadal dysgenesis in both Denys-Drash and Frasier syndrome patients as well as in knockout 
mouse models indicate that WT1 plays also a role in gonadal sex (testis) determination.

Another gene important for early gonadal development is CBX2 (chromobox homolog 2, also known as M33 in the mouse), which shows similarity to the Drosophila polycomb group of genes. Mice carrying a disrupted $C b \times 2$ gene show defects in adrenal, splenic and gonadal development associated with varying degrees of XY sex reversal [Katoh-Fukui et al., 1998]. Further analysis of these mice revealed reduced expression levels of several testis genes, including Sry [Katoh-Fukui et al., 2012]. Interestingly, a recent report describes a $C B X 2$ loss-offunction mutation in a case of $46, \mathrm{XY}$ DSD gonadal dysgenesis with a completely normal female phenotype [Biason-Lauber et al., 2009].

$S R Y$ (sex determining region on the $\mathrm{Y}$ chromosome) is a single exon gene that encodes a 79-amino-acid motif, the HMG box, which is capable of sequence-specific binding and bending of DNA [Giese et al., 1992]. Only the HMG box of SRY is conserved between mammalian species, suggesting that the SRY protein acts as an architectural transcription factor influencing the expression of its target genes by inducing conformational changes in the surrounding chromatin. SRY was isolated using DNA from sex-reversed patients who either carried $2 \mathrm{X}$ chromosomes but formed testes and were phenotypically male (46,XX testicular DSD) or had XY chromosomes and were phenotypically female (46,XY DSD gonadal dysgenesis). Subsequent analysis of these patients showed that $80 \%$ of the 46 ,XX testicular DSD males had some Y chromosome material (including $S R Y$ ) translocated onto one of their X chromosomes, and about $20 \%$ of the $46, \mathrm{XY}$ DSD gonadal dysgenesis females had a loss-of-function mutation in the $S R Y$ gene [Sinclair et al., 1990]. Taken together, these findings confirmed that $S R Y$ was required for testis formation and male gonadal sex determination. Final proof came from the observation that female mice transgenic for the Sry gene developed as males with sterile testes [Koopman et al., 1991]. This demonstrated that $S R Y$ is the only Y-linked gene necessary and sufficient to initiate testis development and thus represents the master testis-determining gene in almost all mammals.

In mice, Sry appears only as a brief burst of expression just prior to morphological differentiation of the embryonic testis [Hanley et al., 2000]. Interestingly in humans, $S R Y$ continues to be expressed in the adult testis [Clépet et al., 1993]. In the mouse embryo, it is expressed in preSertoli cells, and its main function appears to be the initiation of Sertoli cell differentiation. Pre-Sertoli cells stimulate the formation of testicular cords and Leydig cell
Table 1. Genes involved in human sex determination

\begin{tabular}{|c|c|c|}
\hline Gene & Loss of function & Gain of function \\
\hline$C B X 2$ & 46,XY DSD & \\
\hline WT1 & $\begin{array}{l}46, \mathrm{XY} \text { DSD, Denys-Drash and } \\
\text { Frasier syndrome }\end{array}$ & \\
\hline$S R Y$ & $46, \mathrm{XY}$ gonadal dysgenesis & 46,XX testicular DSD \\
\hline SOX9 & $\begin{array}{l}46, \mathrm{XY} \text { gonadal dysgenesis, usually } \\
\text { with campomelic dysplasia }\end{array}$ & 46,XX testicular DSD \\
\hline $\begin{array}{l}\text { NR5A1 } \\
(S F 1)\end{array}$ & $\begin{array}{l}46, \mathrm{XY} \text { gonadal dysgenesis, usually } \\
\text { with adrenal failure }\end{array}$ & \\
\hline $\begin{array}{l}\text { NROB1 } \\
(D A X 1)\end{array}$ & $\begin{array}{l}\text { hypogonadotropic hypogonadism } \\
\text { and congenital adrenal hypoplasia }\end{array}$ & $46, \mathrm{XY}$ gonadal dysgenesis \\
\hline$D M R T 1$ & $46, \mathrm{XY}$ gonadal dysgenesis & \\
\hline$A T R X$ & 46,XY DSD & \\
\hline MAP3K1 & $46, \mathrm{XY}$ gonadal dysgenesis & \\
\hline GATA4 & 46,XY DSD & \\
\hline FOG2 & 46,XY DSD & \\
\hline $\mathrm{DHH}$ & 46,XY DSD & \\
\hline FGF9 & & 46,XX testicular DSD \\
\hline WNT4 & 46,XX testicular DSD & $46, \mathrm{XY}$ gonadal dysgenesis \\
\hline RSPO1 & $\begin{array}{l}\text { 46,XX testicular DSD with } \\
\text { hyperkeratosis }\end{array}$ & \\
\hline
\end{tabular}

formation in the surrounding interstitium. This suggests that Sry acts as a switch toward Sertoli cell fate and testis differentiation, but is, at least in mice, not required for the maintenance or function of the testis.

Several transcription factors have been shown to positively regulate Sry expression, including Wt1, Sf1/Nr5a 1 and Gata4 (GATA binding protein 4) (see below) [Hammes et al., 2001; Tevosian et al., 2002; Wilhelm and Englert, 2002]. As well as transcription factors, epigenetic regulation appears to play an important role in Sry expression as highlighted by a recent publication. The authors of this study showed that knockout of the H3K9 demethylase gene $K d m 3 a$ prevents expression of Sry and leads to male-to-female sex reversal [Kuroki et al., 2013].

\section{Testis Development}

Several autosomal genes are known to play a role downstream of $S R Y$ in testis development. Copy number variation and mutations in these genes are associated with DSD (table 1). Unlike the male Y-specific $S R Y$ gene, these genes are present in both sexes but show differential sex-specific expression.

SOX9 (SRY-related HMG box 9) is a transcription factor essential for both gonadal and skeletal development. It belongs to the same family of developmental regulators as SRY, the SOX proteins. In contrast to SRY, SOX9 pos- 
sesses both a DNA-binding HMG box and a transactivation domain. SOX9 is expressed in a variety of fetal tissues including brain, testis and chondrocytes [Wright et al., 1995]. Mutations in SOX9 are associated with campomelic dysplasia, a rare congenital skeletal malformation syndrome, characterized by anomalies of the ribs and vertebral column, bowing of the long bones and short stature. About $75 \%$ of $46, \mathrm{XY}$ individuals with campomelic dysplasia develop as phenotypic females or present with ambiguous genitalia. Loss-of-function mutations in one allele of SOX 9 have been identified in patients with campomelic dysplasia and 46,XY DSD [Foster et al., 1994; Wagner et al., 1994]. This indicates that haploinsufficiency of SOX9 is responsible for both conditions. Duplication of the chromosome 17q region, including SOX9, can also result in $46, \mathrm{XX}$ testicular DSD, probably due to an increase in SOX9 expression levels [Huang et al., 1999]. Similarly, in mice, Sox9 gain-of-function in XX transgenic mice leads to testis development, whereas loss-of-function results in complete XY sex reversal [Vidal et al., 2001; Barrionuevo et al., 2006]. This suggests that, like SRY, SOX9 is both necessary and sufficient for male development.

In the mouse, Sox 9 is upregulated specifically in preSertoli cells suggesting its role is to induce Sertoli cell differentiation [Sekido et al., 2004]. Sox9 is expressed in the embryonic gonad just after the onset of Sry expression but, unlike Sry, is expressed throughout embryogenesis and adult life. It has long been assumed that SOX9 is a direct target of SRY. However, as the regulatory region of SOX9 spans over more than a megabase of genomic DNA and the proximal promoter region could not be shown to contain a functional SRY binding site [Kanai and Koopman, 1999; Gordon et al., 2009], the SRY-SOX9 relationship remained speculative. In 2008, Sekido and LovellBadge [2008] described an enhancer approximately $13 \mathrm{~kb}$ upstream of Sox9 (testis-specific enhancer of Sox9 core, TESCO). In mice, SRY binds synergistically with SF1 to this enhancer and induces upregulation of Sox9. After SRY expression ceases, SRY is replaced by SOX9 at this enhancer to maintain its own expression [Sekido and Lovell-Badge, 2008]. However, this interaction has not been confirmed in other species. Furthermore, it is unlikely that this enhancer is the only region responsible for SOX9-regulated gonad expression. Recent studies show that rearrangements of genomic regions far upstream of SOX9 can lead to sex reversal in humans [Benko et al., 2011; Cox et al., 2011; Vetro et al., 2011]. Current evidence suggests that the main function of SRY is the initiation of SOX9 upregulation. In contrast to SRY, SOX9 is present in all vertebrates examined so far. This suggests that the crucial event in male development is the upregulation and maintenance of SOX9 expression levels in the testis. While SRY is responsible for the initiation, other factors are required for the maintenance of SOX 9 expression (see below).

In mice, SRY is only expressed for a very brief interval, so other genes must ensure maintenance of Sox 9 expression at levels high enough for testis development. One of these genes is Fgf9, a member of the fibroblast growth factor family. FGFs are involved in many developmental processes in the embryo including cell migration, survival, differentiation, and proliferation. Fgf9 is expressed at low levels in both sexes but becomes upregulated in the developing testis shortly after the onset of Sry. Fgf9 null mice were shown to display XY gonadal dysgenesis with impaired Sertoli cell development [Colvin et al., 2001]. SOX9 expression is not maintained at levels high enough to ensure testis development in these mice, leading to the expression of ovarian genes and male-to-female sex reversal. Current evidence suggests that SOX9 upregulates Fgf9, which in turn triggers a SOX9/FGF9 positive feedback loop to maintain high levels of Sox9 expression in the developing testis. It was shown that, in the testis, FGF9 exerts its function through its receptor FGFR2 [Schmahl et al., 2004]. Unsurprisingly, Fgfr2 null mice are phenotypically very similar to Fgf9 null mice [Bagheri-Fam et al., 2008]. In humans, singlenucleotide variations in FGFR2 have been identified in several hypospadias patients [Beleza-Meireles et al., 2007]. Furthermore, 2 recent reports of CNVs, a duplication of FGF9 in a 46,XX male [Chiang et al., 2013] and a deletion of FGFR2 in a 46,XY female with ambiguous genitalia [TannourLouet et al., 2010], suggest an involvement of both genes in human gonadal development. However, further research is required to confirm their causal role in human DSDs.

Desert hedgehog $(D H H)$ is a member of the hedgehog gene family that encodes signaling molecules involved in the regulation of morphogenesis. DHH is the only member of this family that has been shown to play a role in testis development and fertility. In humans, homozygous missense mutations in $\mathrm{DHH}$ cause $46, \mathrm{XY}$ complete or partial gonadal dysgenesis with or without minifascicular polyneuropathy [Umehara et al., 2000; Canto et al., 2004]. Although Dhh knockout mice are sterile and show lower levels of testosterone due to impaired Leydig cell function, they do not display sex reversal [Bitgood et al., 1996]. In mice, $\mathrm{DHH}$ is therefore thought to induce proper Leydig cell differentiation in the developing testis. 
The Drosophila $d s x$ (doublesex) gene and the Caenorhabditis elegans mab-3 (male abnormal) gene encode transcription factors involved in sexual differentiation. Both these transcription factors bind their target DNA via a so-called DM domain. A search for DM-related genes in humans revealed, amongst others, the DMRT1 (DM-related transcription factor 1) gene [Raymond et al., 1998]. Interestingly, expression of $D M R T 1$ was shown to be restricted to testes in humans and mice. Monosomy of the chromosome $9 \mathrm{p}$ region, including $D M R T 1$, is associated with 46,XY DSD [Raymond et al., 1999]. However, Dmrt1 null mice do not show male-to-female sex reversal. DMRT1's main role appears to be in postnatal Sertoli and germ cell maintenance [Raymond et al., 2000]. Interestingly, in the chicken, knockdown of $D M R T 1$ leads to feminization of genetically male gonads. This suggests that in birds, which lack SRY, DMRT1 has evolved as the critical testis-determining gene. It also indicates that DMRT1 plays an important role in several aspects of vertebrate testicular development [Smith et al., 2009]. A recent report highlights the important function of DMRT1 in maintenance of functional testes in adult life (see below).

AMH (anti-Müllerian hormone) is a member of the transforming growth factor-beta family and one of the first hormones produced by the developing testis. It is synthesized in Sertoli cells and causes regression of the Müllerian ducts, which in females develop as oviducts, uterus and upper vagina [Cate et al., 1986]. AMH is therefore required for sex-specific differentiation of the reproductive tract; however, lack of AMH does not affect testicular differentiation itself. In mice, SOX9 was shown to be essential for initiating Amh expression, while SF1 directly interacts with both SOX9 and WT1 to significantly upregulate $A m h$ transcript levels in male embryos [Arango et al., 1999].

NROB1/DAX1 (nuclear receptor subfamily 0 , group $\mathrm{B}$, member 1/DSS-AHC critical region of the X chromosome, gene 1) encodes an unusual orphan nuclear receptor with a ligand-binding domain but lacking the characteristic nuclear receptor zinc finger DNA-binding domain. Duplications of DAX1 have been shown to cause 46,XY DSD [Baumstark et al., 1996; Sanlaville et al., 2004]. While loss-of-function mutations or deletions of the $D A X 1$ gene result in patients with adrenal hypoplasia congenita and hypogonadotropic hypogonadism, no effect on testicular development was observed [Muscatelli et al., 1994]. Similarly, transgenic mice that overexpress Daxl display gonadal abnormalities in male mice, with the severity depending on the mouse strain [Swain et al.,
1998]. In contrast to humans, XY Dax1 null mice do show defects in testis development [Yu et al., 1998]. Dax1 is expressed during the critical time window of early gonadal sex determination. After Sry expression ceases, Daxl is downregulated in the developing testis but maintains its expression levels in the ovary [Swain et al., 1998]. DAX1 has been shown by in vitro experiments to interact with SF1 thereby repressing the synergistic action of SF1 and WT1 on the Amh promoter [Nachtigal et al., 1998]. Dax1 null XX female mice develop functional ovaries, suggesting that $D A X 1$ is not an ovarian-determining gene but, if duplicated, acts antagonistically to $S R Y$ as an anti-testis gene. Klinefelter's syndrome (XXY) individuals are male, not sex-reversed females and this is likely due to X chromosome inactivation of DAX1. It has been suggested that DAX1 might function within an activity window [Ludbrook and Harley, 2004]. If DAX1 is present in a certain concentration, it can promote proper testis development. On the other hand, too little or too much DAX1 activity leads to misregulated testis development.

ATRX is a member of the SWI/SNF family of chromatin-remodeling proteins. Mutations and deletions of the $A T R X$ gene cause the alpha-thalassemia/mental retardation syndrome, X-linked [Gibbons et al., 1995]. XY patients additionally show varying degrees of 46,XY DSD, implicating alpha-thalassemia/mental retardation syndrome in testis development [Reardon et al., 1995]. However, the range of observed genital phenotypes, from small testes to ambiguous external genitalia, and the lack of complete male-to-female sex reversal suggest ATRX plays a role in sex (testis) differentiation rather than in the earlier gonadal sex (testis) determination.

GATA4 is one of 6 members of the evolutionarily conserved GATA family of transcription factors. GATA factors contain 2 zinc finger domains that have been shown to be critical for DNA recognition and binding, as well as for protein-protein binding with other transcription cofactors. GATA4 has been shown to be expressed in somatic cells in the gonads of both sexes before and during the time of sex determination [Viger et al., 1998]. In the mouse, Gata4 expression becomes testis-specific at E13.5, and its expression is maintained in Sertoli cells after birth. GATA4 usually interacts with other transcription factors to regulate the expression of its target genes. Two wellknown partners are NR5A1/SF1 and FOG2/ZFPM2 (friend of GATA-2/zinc finger protein, FOG family member 2). Together, they have been shown to regulate the sex determination and differentiation genes SRY, SOX 9 and $A M H$, as well as STAR (steroidogenic acute regulatory protein), CYP19A1 (cytochrome P450, family 19, sub- 
family A, polypeptide 1) and HSD3B2 (hydroxyl-delta5-steroid dehydrogenase, 3 beta- and steroid delta-isomerase 2). Gata4 ${ }^{-/}$mice die before the development of bipotential gonads; however, Gata $4^{k i}$ mice carrying a mutation in the $\mathrm{N}$-terminal zinc finger domain, which prevents the interaction with FOG2, exhibit severe anomalies of testis development [Bouma et al., 2007]. Most described mutations in human GATA4 have been linked to congenital heart defects (CHD) only. However, a recent study reported a familial case of a heterozygous mutation in GATA4 with three 46,XY DSD and two 46,XX CHD cases [Lourenço et al., 2011]. In another study, a 35-kb deletion downstream of GATA4 was discovered in a $46, \mathrm{XY}$ complete gonadal dysgenesis patient without $\mathrm{CHD}$ [White et al., 2011].

FOG2 was shown to repress GATA4-dependent activation of Amh expression in rat primary Sertoli cells. Fog $2^{-/-}$mice show a block of gonadal development and fail to develop testes. However, it is unclear whether FOG2 acts as an activator or repressor (or both) of gonadal gene expression. So far, only one translocation including FOG2 (leading to a truncated FOG2 protein) in a boy with hypergonadotropic hypogonadism and $\mathrm{CHD}$ has been described [Finelli et al., 2007].

Two members of the mitogen-activated protein kinase (MAPK) signaling pathway, MAP3K1 and Map3k4, have recently been added to the growing list of genes involved in testis development. Linkage analysis of 2 affected families and gene sequencing of several individuals with $46, \mathrm{XY}$ DSD revealed mutations in the MAP3K1 gene as the likely cause for the condition [Pearlman et al., 2010]. In mice, $M a p 3 k 1$ appears to play only a minor role in testis development as Map3k1 null mice do not show gonadal abnormalities [Warr et al., 2011]. However, using a forward genetic screen in mice, a mutation in the Map $3 k 4$ gene responsible for male-to-female sex reversal was discovered. Expression analysis of Map3k4 null XY gonads revealed a dramatic reduction of Sry and Sox 9 expression [Bogani et al., 2009]. A recent report proposed a model of interaction to explain this observation [Warr et al., 2012]. According to this model, GADD45G (growth arrest and DNA-damage-inducible 45 gamma) activates MAP3K4, which in turn leads to the activation of $\mathrm{p} 38$ MAP kinases (MAPK11/MAPK14) and subsequently GATA4, an important transcriptional regulator of several testis genes, including Sry and Sox9. Taken together, these findings point to an important function of the MAPK signaling pathway in testis development.

\section{Ovarian Development}

Until very recently, the pathway leading to ovarian development was considered to be a passive or 'default' pathway, and little was known about the underlying molecular mechanisms leading to functional ovaries. However, in recent years, several important players of ovarian development have been identified, and it has become clear that the ovarian pathway is not passive. Furthermore, it has become apparent that components of both male and female pathways antagonize each other to ensure proper development of either testes or ovaries.

CTNNB1/beta catenin (catenin, beta 1) is a key component of the WNT (wingless-type MMTV integration site famliy) signaling pathway and a central player in ovarian development. It acts as a transcriptional regulator and, if activated by WNT ligand binding, executes its function by binding to TCF/LEF (transcription factor/ lymphoid enhancer-binding factor 1) transcription factors that in turn activate the expression of their target genes. In the absence of beta-catenin, TCF/LEF acts as a transcriptional repressor by recruiting Groucho proteins [Eastman and Grosschedl, 1999]. In mice, stabilization by phosphorylation of beta-catenin in XY gonads has been shown to promote ovarian development and suppress testis development, leading to XY sex reversal [Maatouk et al., 2008]. The role of beta-catenin in human gonadal development has not so far been established. However, 2 signaling molecules that activate beta-catenin, WNT4 and $R S P O 1$ (R-spondin 1) (see below), are upregulated in the female gonad and - in contrast to beta-catenin - have been shown to cause DSDs.

The WNT gene family encodes locally acting signaling molecules that are involved in a wide range of developmental processes. WNT4 is its most important member in gonadal development. In the mouse, Wnt4 is initially expressed in both sexes. While its expression levels are increasing in the ovary during gonad differentiation, it is downregulated in the testis from 12.5 days post coitum. In humans, homozygous null mutations were shown to cause 46,XX testicular DSD [Mandel et al., 2008]. Interestingly, Wnt4 knockout XX mice show a milder phenotype with only partial sex reversal. These mice lacked Müllerian ducts and failed to maintain oocytes [Vainio et al., 1999]. Furthermore, overexpression of Wnt4 in XY mice results in disruption of testicular vasculature and inhibition of testosterone production by suppressing Leydig cell development, but does not lead to sex reversal [Jordan et al., 2003]. Taken together, these findings show that WNT4 alone is not able to override the male devel- 
Fig. 1. Overview of the genes and their interactions in gonadal sex determination. Arrows indicate activation of a downstream target. Lines ending in bars indicate repression of a downstream target. The interactions shown are not necessarily direct. KDM3A was not included as its effects are epigenetic. Refer to the text for more detailed information.

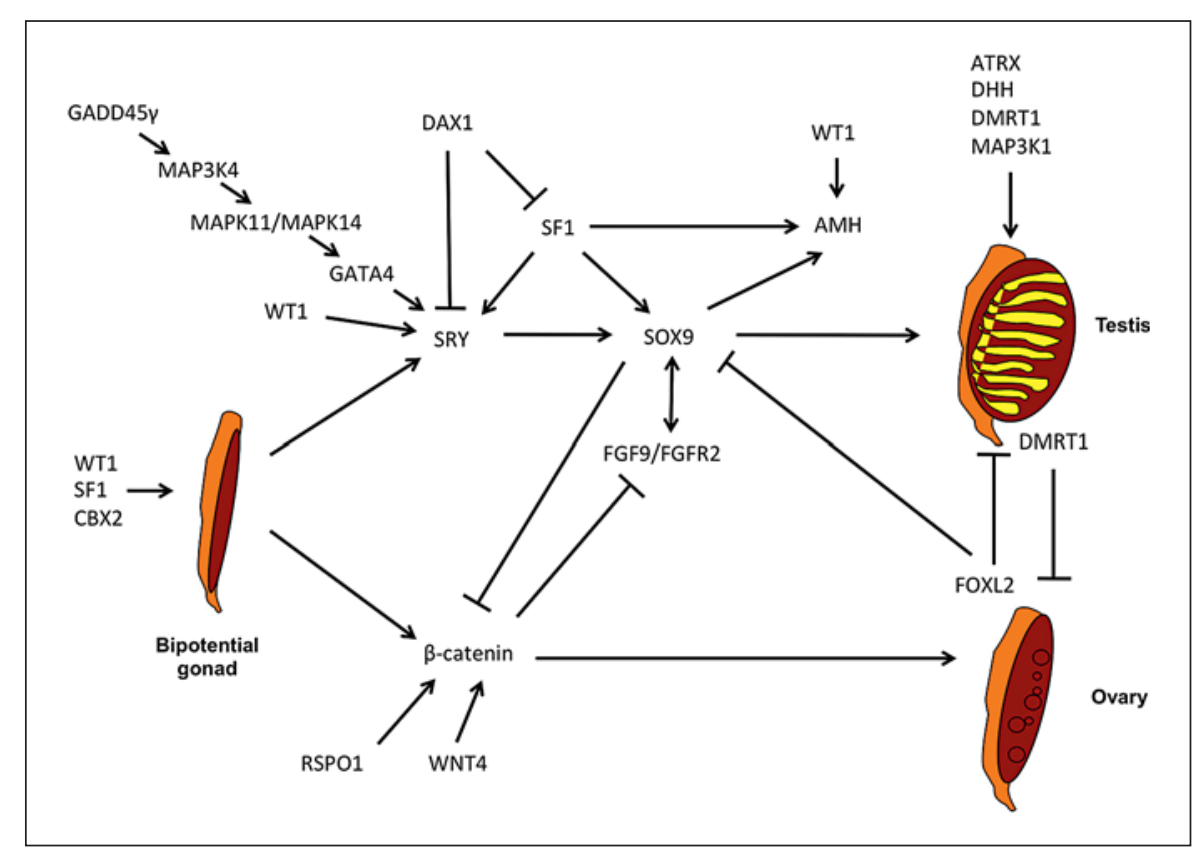

opmental program, and hence, WNT4 on its own cannot be the sole ovarian determinant.

Homozygous null mutations in RSPO1, a member of the R-spondin family, were shown to cause 46 , XX testicular DSD in humans [Parma et al., 2006]. This was the first report of a single gene mutation leading to female-tomale sex reversal. RSPO1 is thought to activate and then synergize with WNT4 in embryonic ovaries to stabilize beta-catenin and thereby allowing the female pathway to proceed [Chassot et al., 2008]. The conservation and expression pattern of RSPO1 in other vertebrates points to an important role in female sex determination. In mice however, it appears to act together with other factors, as Rspo1 null mice display only partial sex reversal [Tomizuka et al., 2008]. Interestingly, a human patient with a duplication of chromosome 1p, containing both WNT4 and RSPO1, had a female phenotype with 46,XY DSD [Jordan et al., 2001]. Presumably, the duplication has affected expression of WNT4 and RSPO1.

FOXL2 is a member of the evolutionarily conserved forkhead box (FOX) superfamily of transcription factors. In vertebrates, FOXL2 is one of the earliest markers of ovarian development. In goats, a deletion affecting the expression of FOXL2 has been shown to cause female-tomale sex reversal [Pailhoux et al., 2001]. In humans, lossof-function mutations of FOXL2 cause blepharophimosis, ptosis and epicanthus inversus syndrome, a genetic disorder leading to complex eyelid malformation and other craniofacial abnormalities [Crisponi et al., 2001]. This syndrome can be associated with premature ovarian insufficiency, suggesting a role for FOXL2 in follicle maintenance during adult life [Harris et al., 2002]. However, no link between FOXL2 and human DSD has been established so far. While XX Foxl2 null mice show only masculinization of the supporting cells in the gonad, double knockouts of both Foxl2 and Wnt4 lead to female-tomale sex reversal and development of male germ cells [Ottolenghi et al., 2007]. Interestingly, FOXL2 also plays an important role in maintaining functional ovaries in adult mice (see below). The exact relationship between RSPO1/WNT4 and FOXL2 in coordinating ovarian development remains unclear.

\section{Testes and Ovaries Actively Suppress Opposing Pathways to Ensure Their Proper Development and Maintenance}

Components of both male and female sex differentiation pathways have been shown to act antagonistically (fig. 1). During embryonic development the main players appear to be SOX9 and beta-catenin. In males, SRY-induced increased expression of SOX9 limits the expression of female-specific genes. The positive feedback loop of SOX9 and FGF9 actively suppresses the activation of WNT4 to tip the balance towards testis development 
[Kim et al., 2006]. By contrast, beta-catenin, stabilized and activated by WNT4 and RSPO1, limits the expression of SOX9 by inhibiting the SOX9/FGF9 feedback loop to ensure the development of ovaries in females [Maatouk et al., 2008]. Recently, an additional player has been added to the opposing testicular and ovarian pathways. Loke et al. [2013] were able to show that splice-site and missense mutations of MAP3K1 tilt the balance from male (FGF9/SOX9) to the female (WNT4/beta-catenin) pathway.

The battle of the sexes is not completely resolved during embryogenesis but continues into adulthood long after gonadal sex determination and differentiation are completed. Female Cyp19a1 knockout mice have been shown to contain Sertoli-like cells in their ovaries. However, estradiol administration reverses the transdifferentiation of granulosa cells into Sertoli-like cells in female Cyp19a1 knockout mice [Britt et al., 2004]. Further evidence for this life-long battle came from 2 recent remarkable publications that analyzed the role of FOXL2 and DMRT1 in adult ovaries and testes, respectively. In mice, when Foxl2 is conditionally knocked out in granulosa cells of fully differentiated adult ovaries, a striking event occurs. The granulosa cells of the ovary transdifferentiate into Sertoli-like cells, theca cells become Leydig cells and, instead of the typical follicular structure of an ovary, the gonads resemble a testis in appearance with seminiferous tubules [Uhlenhaut et al., 2009]. This clearly indicates that FOXL2 is required for maintenance of adult ovaries and suppression of the testicular pathway throughout adult life. On the other hand, when Dmrt1 is conditionally knocked out in postnatal Sertoli cells, Foxl2 becomes activated, Sertoli cells transdifferentiate into granulosa cells, the gonads start to produce estrogen, and germ cells become feminized [Matson et al., 2011]. This clearly shows that DMRT1 is necessary to maintain the adult testis. Surprisingly, both testes and ovaries appear labile even after birth and apparently require constitutive gene expression to suppress the opposing pathway from being activated.

\section{Novel Strategies to Identify Missing Components of Sex Differentiation Pathways}

As most cases of DSD lead to infertility, many mutations affecting sex determination and development are spontaneous, and familial cases are not very common. Recent analyses of DSD patients using SNP arrays to identify genome-wide duplications and deletions have identified many rearrangements in intergenic regions, some of them in proximity to known sex genes [White et al., 2011]. This strongly suggests that many cases of these disorders might be due to disruptions of regulatory regions of sex determination and differentiation genes. Even ectopic expression of nongonadal genes can lead to DSD. In a recent study, genomic rearrangements surrounding or including SOX3 were found in several 46,XX testicular DSD patients [Sutton et al., 2011]. The X-linked SOX3 gene - considered to be the ancestor of the Y-linked $S R Y$ - is normally not expressed in gonads at any developmental stage. It is therefore likely that the rearrangements led to ectopic expression of $\mathrm{SOX} 3$ in the developing gonads of these patients during embryonic development, where it was able to substitute for SRY and drive the testicular pathway.

Despite recent technical advancements, it is still very laborious and difficult to identify the exact location and unravel the function of regulatory regions. Chromatin immunoprecipitation followed by deep sequencing using antibodies for transcription factors involved in gonadal development and differentiation (e.g. SOX9 and FOXL2) will help to identify important targets of these transcription factors and likely lead to the discovery of hitherto unknown gonadal genes. The same approach using antibodies specific for certain chromatin marks (e.g. $\mathrm{H} 3 \mathrm{~K} 4 \mathrm{me} 1, \mathrm{H} 3 \mathrm{~K} 27 \mathrm{Ac}$ ) will increase our understanding of the regulation of gonadal genes by identifying their enhancers and promoters. Due to the nature of SNP arrays and their limitation in resolution, rearrangements smaller than $5-10 \mathrm{~kb}$ cannot be detected by these arrays. However, due to technological advances and the rapidly falling costs, it will soon be feasible to routinely perform whole exome or even whole genome sequencing of DSD patients to detect genomic rearrangements and mutations down to the single nucleotide level. The next big challenge will be to make sense of the massive amounts of data generated by these new technologies.

\section{Concluding Remarks}

Since the discovery of $S R Y$ over 2 decades ago, there has been a dramatic increase in our understanding of the molecular mechanisms and genetic interactions involved in human sex determination and differentiation. The identification and characterization of several key genes has helped to elucidate the complexity inherent in the development of functional testes and ovaries. However, many questions concerning sexual development still re- 
main unanswered. The majority of human DSD cases still cannot be explained. While environmental factors might play a role, it is likely that more components of this complex genetic network await discovery. Rapidly evolving technology such as massively parallel sequencing of DSD patients will enable us to identify more genes that are components of the testis and ovarian pathways. This will not only provide insights into human gonadal sex determination and sexual differentiation but also will assist with the diagnosis and subsequent clinical management of patients with DSD.

\section{References}

Achermann JC, Ito M, Ito M, Hindmarsh PC, Jameson JL: A mutation in the gene encoding steroidogenic factor- 1 causes XY sex reversal and adrenal failure in humans. Nat Genet 22: 125-126 (1999).

-Arango NA, Lovell-Badge R, Behringer RR: Targeted mutagenesis of the endogenous mouse Mis gene promoter: in vivo definition of genetic pathways of vertebrate sexual development. Cell 99:409-419 (1999).

- Bagheri-Fam S, Sim H, Bernard P, Jayakody I, Taketo MM, et al: Loss of Fgfr2 leads to partial XY sex reversal. Dev Biol 314:71-83 (2008).

-Barbaux S, Niaudet P, Gubler MC, Grünfeld JP, Jaubert F, et al: Donor splice-site mutations in WT1 are responsible for Frasier syndrome. Nat Genet 17:467-470 (1997).

-Barrionuevo F, Bagheri-Fam S, Klattig J, Kist R, Taketo MM, et al: Homozygous inactivation of Sox 9 causes complete XY sex reversal in mice. Biol Reprod 74:195-201 (2006).

-Baskin LS, Himes K, Colborn T: Hypospadias and endocrine disruption: is there a connection? Environ Health Perspect 109:1175-1183 (2001).

Baumstark A, Barbi G, Djalali M, Geerkens C, Mitulla B, et al: Xp-duplications with and without sex reversal. Hum Genet 97:79-86 (1996).

-Beleza-Meireles A, Lundberg F, Lagerstedt K, Zhou X, Omrani D, et al: FGFR2, FGF8, FGF10 and BMP7 as candidate genes for hypospadias. Eur J Hum Genet 15:405-410 (2007).

Benko S, Gordon CT, Mallet D, Sreenivasan R, Thauvin-Robinet C, et al: Disruption of a long distance regulatory region upstream of SOX 9 in isolated disorders of sex development. J Med Genet 48:825-830 (2011).

Biason-Lauber A, Konrad D, Meyer M, DeBeaufort C, Schoenle EJ: Ovaries and female phenotype in a girl with 46,XY karyotype and mutations in the CBX2 gene. Am J Hum Genet 84:658-663 (2009).

Bitgood MJ, Shen L, McMahon AP: Sertoli cell signaling by Desert hedgehog regulates the male germline. Curr Biol 6:298-304 (1996).

- Bogani D, Siggers P, Brixey R, Warr N, Beddow S, et al: Loss of mitogen-activated protein kinase kinase kinase 4 (MAP3K4) reveals a requirement for MAPK signalling in mouse sex determination. PLoS Biol 7:e1000196 (2009).
Bouma GJ, Washburn LL, Albrecht KH, Eicher EM: Correct dosage of Fog2 and Gata4 transcription factors is critical for fetal testis development in mice. Proc Natl Acad Sci USA 104:14994-14999 (2007).

Britt KL, Stanton PG, Misso M, Simpson ER, Findlay JK: The effects of estrogen on the expression of genes underlying the differentiation of somatic cells in the murine gonad. Endocrinology 145:3950-3960 (2004).

Canto P, Söderlund D, Reyes E, Méndez JP: Mutations in the desert hedgehog $(\mathrm{DHH})$ gene in patients with $46, \mathrm{XY}$ complete pure gonadal dysgenesis. J Clin Endocrinol Metab 89:44804483 (2004).

Cate RL, Mattaliano RJ, Hession C, Tizard R, Farber NM, et al: Isolation of the bovine and human genes for Müllerian inhibiting substance and expression of the human gene in animal cells. Cell 45:685-698 (1986).

Chassot A-A, Ranc F, Gregoire EP, Roepers-Gajadien HL, Taketo MM, et al: Activation of beta-catenin signaling by Rspol controls differentiation of the mammalian ovary. Hum Mol Genet 17:1264-1277 (2008).

Chiang H-S, Wu Y-N, Wu C-C, Hwang J-L: Cytogenic and molecular analyses of 46,XX male syndrome with clinical comparison to other groups with testicular azoospermia of genetic origin. J Formos Med Assoc 112:72-78 (2013).

Clépet C, Schafer AJ, Sinclair AH, Palmer MS, Lovell-Badge R, Goodfellow PN: The human SRY transcript. Hum Mol Genet 2:2007-2012 (1993).

Colvin JS, Green RP, Schmahl J, Capel B, Ornitz DM: Male-to-female sex reversal in mice lacking fibroblast growth factor 9. Cell 104:875889 (2001).

Cox JJ, Willatt L, Homfray T, Woods CG: A SOX9 duplication and familial 46,XX developmental testicular disorder. N Engl J Med 364:9193 (2011)

Crisponi L, Deiana M, Loi A, Chiappe F, Uda M, et al: The putative forkhead transcription factor FOXL2 is mutated in blepharophimosis/ ptosis/epicanthus inversus syndrome. Nat Genet 27:159-166 (2001).

Eastman Q, Grosschedl R: Regulation of LEF-1/ TCF transcription factors by Wnt and other signals. Curr Opin Cell Biol 11:233-240 (1999).
Finelli P, Pincelli AI, Russo S, Bonati MT, Recalcati MP, et al: Disruption of friend of GATA 2 gene $(F O G-2)$ by a de novo $t(8 ; 10)$ chromosomal translocation is associated with heart defects and gonadal dysgenesis. Clin Genet 71:195-204 (2007).

Foster JW, Dominguez-Steglich MA, Guioli S, Kwok C, Weller PA, et al: Campomelic dysplasia and autosomal sex reversal caused by mutations in an SRY-related gene. Nature 372:525-530 (1994).

Gibbons RJ, Picketts DJ, Villard L, Higgs DR: Mutations in a putative global transcriptional regulator cause $\mathrm{X}$-linked mental retardation with alpha-thalassemia (ATR-X syndrome). Cell 80:837-845 (1995).

Giese K, Cox J, Grosschedl R: The HMG domain of lymphoid enhancer factor 1 bends DNA and facilitates assembly of functional nucleoprotein structures. Cell 69:185-195 (1992).

Gordon CT, Tan TY, Benko S, FitzPatrick D, Lyonnet S, Farlie PG: Long-range regulation at the SOX9 locus in development and disease. J Med Genet 46:649-656 (2009).

-Hammes A, Guo JK, Lutsch G, Leheste JR, Landrock D, et al: Two splice variants of the Wilms' tumor 1 gene have distinct functions during sex determination and nephron formation. Cell 106:319-329 (2001).

-Hanley NA, Hagan DM, Clement-Jones M, Ball SG, Strachan T, et al: SRY, SOX9, and DAX1 expression patterns during human sex determination and gonadal development. Mech Dev 91:403-407 (2000).

-Harris SE, Chand AL, Winship IM, Gersak K, Aittomäki K, Shelling AN: Identification of novel mutations in FOXL2 associated with premature ovarian failure. Mol Hum Reprod 8: 729-733 (2002).

Hohenstein P, Hastie ND: The many facets of the Wilms' tumour gene, WT1. Hum Mol Genet 15 Spec No 2:R196-R201 (2006).

-Huang B, Wang S, Ning Y, Lamb AN, Bartley J: Autosomal XX sex reversal caused by duplication of SOX9. Am J Med Genet 87:349-353 (1999).

Hughes IA, Houk C, Ahmed SF, Lee PA, LWPES Consensus Group, ESPE Consensus Group: Consensus statement on management of intersex disorders. J Pediatr Urology 2:148-162 (2006). 
-Jordan BK, Mohammed M, Ching ST, Délot E, Chen XN, et al: Up-regulation of WNT-4 signaling and dosage-sensitive sex reversal in humans. Am J Hum Genet 68:1102-1109 (2001).

- Jordan BK, Shen JH-C, Olaso R, Ingraham HA, Vilain E: Wnt4 overexpression disrupts normal testicular vasculature and inhibits testosterone synthesis by repressing steroidogenic factor 1/beta-catenin synergy. Proc Natl Acad Sci USA 100:10866-10871 (2003).

Kanai Y, Koopman P: Structural and functional characterization of the mouse Sox 9 promoter: implications for campomelic dysplasia. Hum Mol Genet 8:691-696 (1999).

-Katoh-Fukui Y, Tsuchiya R, Shiroishi T, Nakahara $\mathrm{Y}$, Hashimoto $\mathrm{N}$, et al: Male-to-female sex reversal in M33 mutant mice. Nature 393: 688-692 (1998).

Katoh-Fukui Y, Miyabayashi K, Komatsu T, Owaki A, Baba T, et al: $C b x 2$, a polycomb group gene, is required for Sry gene expression in mice. Endocrinology 153:913-924 (2012).

-Kim Y, Kobayashi A, Sekido R, DiNapoli L, Brennan J, et al: $F g f 9$ and $W n t 4$ act as antagonistic signals to regulate mammalian sex determination. PLoS Biol 4:e187 (2006).

Koopman P, Gubbay J, Vivian N, Goodfellow P, Lovell-Badge R: Male development of chromosomally female mice transgenic for Sry. Nature 351:117-121 (1991).

-Kreidberg JA, Sariola H, Loring JM, Maeda M, Pelletier J, et al: WT-1 is required for early kidney development. Cell 74:679-691 (1993).

- Kuroki S, Matoba S, Akiyoshi M, Matsumura Y, Miyachi $\mathrm{H}$, et al: Epigenetic regulation of mouse sex determination by the histone demethylase Jmjd1a. Science 341:1106-1109 (2013).

Loke J, Pearlman A, Radi O, Zuffardi O, Giussani $\mathrm{U}$, et al: Mutations in MAP3K1 tilt the balance from SOX9/FGF9 to WNT/beta-catenin signaling. Hum Mol Genet (2013), E-pub ahead of print.

-Lourenço D, Brauner R, Lin L, De Perdigo A, Weryha G, et al: Mutations in NR5A1 associated with ovarian insufficiency. N Engl J Med 360:1200-1210 (2009).

Lourenço D, Brauner R, Rybczynska M, NihoulFékété C, McElreavey K, Bashamboo A: Lossof-function mutation in GATA4 causes anomalies of human testicular development. Proc Natl Acad Sci USA 108:1597-1602 (2011).

Ludbrook LM, Harley VR: Sex determination: a 'window' of DAX1 activity. Trends Endocrinol Metab 15:116-121 (2004).

- Luo X, Ikeda Y, Parker KL: A cell-specific nuclear receptor is essential for adrenal and gonadal development and sexual differentiation. Cell 77:481-490 (1994).

-Maatouk DM, DiNapoli L, Alvers A, Parker KL, Taketo MM, Capel B: Stabilization of betacatenin in XY gonads causes male-to-female sex-reversal. Hum Mol Genet 17:2949-2955 (2008).
Mandel H, Shemer R, Borochowitz ZU, Okopnik M, Knopf C, et al: SERKAL syndrome: an autosomal-recessive disorder caused by a lossof-function mutation in WNT4. Am J Hum Genet 82:39-47 (2008).

Matson CK, Murphy MW, Sarver AL, Griswold MD, Bardwell VJ, Zarkower D: DMRT1 prevents female reprogramming in the postnatal mammalian testis. Nature 476:101-104 (2011).

Muscatelli F, Strom TM, Walker AP, Zanaria E, Récan D, et al: Mutations in the $D A X-1$ gene give rise to both $\mathrm{X}$-linked adrenal hypoplasia congenita and hypogonadotropic hypogonadism. Nature 372:672-676 (1994).

- Nachtigal MW, Hirokawa Y, Enyeart-VanHouten DL, Flanagan JN, Hammer GD, Ingraham HA: Wilms' tumor 1 and Dax-1 modulate the orphan nuclear receptor SF-1 in sex-specific gene expression. Cell 93:445-454 (1998).

-Ottolenghi C, Pelosi E, Tran J, Colombino M, Douglass E, et al: Loss of Wnt4 and Foxl2 leads to female-to-male sex reversal extending to germ cells. Hum Mol Genet 16:2795-2804 (2007).

Pailhoux E, Vigier B, Chaffaux S, Servel N, Taourit $\mathrm{S}$, et al: A 11.7-kb deletion triggers intersexuality and polledness in goats. Nat Genet 29:453-458 (2001).

Parma P, Radi O, Vidal V, Chaboissier M-C, Dellambra E, et al: R-spondin 1 is essential in sex determination, skin differentiation and malignancy. Nat Genet 38:1304-1309 (2006).

- Pearlman A, Loke J, Le Caignec C, White S, Chin L, et al: Mutations in MAP3K1 cause 46,XY disorders of sex development and implicate a common signal transduction pathway in human testis determination. Am J Hum Genet 87:898-904 (2010).

- Pelletier J, Bruening W, Kashtan CE, Mauer SM, Manivel JC, et al: Germline mutations in the Wilms' tumor suppressor gene are associated with abnormal urogenital development in Denys-Drash syndrome. Cell 67:437-447 (1991).

Raymond CS, Shamu CE, Shen MM, Seifert KJ, Hirsch B, et al: Evidence for evolutionary conservation of sex-determining genes. Nature 391:691-695 (1998).

-Raymond CS, Parker ED, Kettlewell JR, Brown LG, Page DC, et al: A region of human chromosome 9p required for testis development contains two genes related to known sexual regulators. Hum Mol Genet 8:989-996 (1999).

Raymond CS, Murphy MW, O'Sullivan MG, Bardwell VJ, Zarkower D: Dmrt1, a gene related to worm and fly sexual regulators, is required for mammalian testis differentiation. Genes Dev 14:2587-2595 (2000).

Reardon W, Gibbons RJ, Winter RM, Baraitser M: Male pseudohermaphroditism in sibs with the alpha-thalassemia/mental retardation (ATR-X) syndrome. Am J Med Genet 55:285287 (1995).
Sanlaville D, Vialard F, Thépot F, Vue-Droy L, Ardalan A, et al: Functional disomy of Xp including duplication of DAX1 gene with sex reversal due to $t(X ; Y)(p 21.2 ; p 11.3)$. Am J Med Genet 128A:325-330 (2004).

Satoh M: The histogenesis of the gonad in rat embryos. J Anat 143:17-37 (1985).

Schmahl J, Kim Y, Colvin JS, Ornitz DM, Capel B: Fgf9 induces proliferation and nuclear localization of FGFR2 in Sertoli precursors during male sex determination. Development 131: 3627-3636 (2004).

- Sekido R, Lovell-Badge R: Sex determination involves synergistic action of SRY and SF1 on a specific Sox9 enhancer. Nature 453:930-934 (2008)

- Sekido R, Bar I, Narváez V, Penny G, LovellBadge R: SOX9 is up-regulated by the transient expression of SRY specifically in Sertoli cell precursors. Dev Biol 274:271-279 (2004).

- Sinclair AH, Berta P, Palmer MS, Hawkins JR, Griffiths BL, et al: A gene from the human sex-determining region encodes a protein with homology to a conserved DNA-binding motif. Nature 346:240-244 (1990).

-Smith CA, Roeszler KN, Ohnesorg T, Cummins DM, Farlie PG, et al: The avian Z-linked gene $D M R T 1$ is required for male sex determination in the chicken. Nature 461:267-271 (2009).

Sutton E, Hughes J, White S, Sekido R, Tan J, et al: Identification of SOX3 as an XX male sex reversal gene in mice and humans. J Clin Invest 121:328-341 (2011).

- Swain A, Narvaez V, Burgoyne P, Camerino G, Lovell-Badge R: Daxl antagonizes Sry action in mammalian sex determination. Nature 391:761-767 (1998).

- Tannour-Louet M, Han S, Corbett ST, Louet J-F, Yatsenko $\mathrm{S}$, et al: Identification of de novo copy number variants associated with human disorders of sexual development. PLoS One 5:e15392 (2010)

- Tevosian SG, Albrecht KH, Crispino JD, Fujiwara Y, Eicher EM, Orkin SH: Gonadal differentiation, sex determination and normal Sry expression in mice require direct interaction between transcription partners GATA4 and FOG2. Development 129:4627-4634 (2002).

Tomizuka K, Horikoshi K, Kitada R, Sugawara Y, Iba $\mathrm{Y}$, et al: R-spondin1 plays an essential role in ovarian development through positively regulating Wnt-4 signaling. Hum Mol Genet 17:1278-1291 (2008).

Uhlenhaut NH, Jakob S, Anlag K, Eisenberger T, Sekido R, et al: Somatic sex reprogramming of adult ovaries to testes by FOXL2 ablation. Cell 139:1130-1142 (2009).

Umehara F, Tate G, Itoh K, Yamaguchi N, Douchi $\mathrm{T}$, et al: A novel mutation of desert hedgehog in a patient with $46, \mathrm{XY}$ partial gonadal dysgenesis accompanied by minifascicular neuropathy. Am J Hum Genet 67:1302-1305 (2000). 
Vainio S, Heikkilä M, Kispert A, Chin N, McMahon AP: Female development in mammals is regulated by Wnt-4 signalling. Nature 397: 405-409 (1999).

- Val P, Lefrançois-Martinez A-M, Veyssière G, Martinez A: SF-1 a key player in the development and differentiation of steroidogenic tissues. Nucl Recept 1:8 (2003).

-Vetro A, Ciccone R, Giorda R, Patricelli MG, Della Mina E, et al: XX males $S R Y$ negative: a confirmed cause of infertility. J Med Genet 48: 710-712 (2011).

-Vidal VP, Chaboissier MC, de Rooij DG, Schedl A: Sox9 induces testis development in $\mathrm{XX}$ transgenic mice. Nat Genet 28:216-217 (2001).
Viger RS, Mertineit C, Trasler JM, Nemer M: Transcription factor GATA-4 is expressed in a sexually dimorphic pattern during mouse gonadal development and is a potent activator of the Müllerian inhibiting substance promoter. Development 125:2665-2675 (1998).

Wagner T, Wirth J, Meyer J, Zabel B, Held M, et al: Autosomal sex reversal and campomelic dysplasia are caused by mutations in and around the SRY-related gene SOX9. Cell 79: 1111-1120 (1994).

-Warr N, Bogani D, Siggers P, Brixey R, Tateossian $\mathrm{H}$, et al: Minor abnormalities of testis development in mice lacking the gene encoding the MAPK signalling component, MAP3K1. PLoS One 6:e19572 (2011).

-Warr N, Carre G-A, Siggers P, Faleato JV, Brixey R, et al: Gadd45gamma and Map3k4 interactions regulate mouse testis determination via p38 MAPK-mediated control of Sry expression. Dev Cell 23:1020-1031 (2012).
-White S, Ohnesorg T, Notini A, Roeszler K, Hewitt J, et al: Copy number variation in patients with disorders of sex development due to $46, \mathrm{XY}$ gonadal dysgenesis. PLoS One 6:e17793 (2011).

Wilhelm D, Englert C: The Wilms tumor suppressor WT1 regulates early gonad development by activation of Sf1. Genes Dev 16: 1839-1851 (2002).

Wright E, Hargrave MR, Christiansen J, Cooper L, Kun J, et al: The Sry-related gene Sox9 is expressed during chondrogenesis in mouse embryos. Nat Genet 9:15-20 (1995).

Yu RN, Ito M, Saunders TL, Camper SA, Jameson JL: Role of Ahch in gonadal development and gametogenesis. Nat Genet 20:353-357 (1998). 